\title{
3D MAGNETIC MODEL OF THE EARTH CRUST OF THE EASTERN EUROPEAN CRATON WITH THE ACCOUNT OF THE EARTH SPHERICITY AND ITS TECTONIC INTERPRETATION
}

\begin{abstract}
(Рекомендовано членами редакційної колегії д-ром геол. наук, проф. О.М. Іванік і д-ром геол. наук, проф. С.А. Вижвою)
The geomagnetic field is widely used to obtain information on the deep structure and development of the Earth's lithosphere, small-scale forecasting of minerals, and the solution of a number of environmental problems. The most significant results are obtained due to the development of 2D, 3D and 4D magnetic models of the Earth's crust (lithosphere) in which the spatial and spatiotemporal distribution of magnetic sources is reflected. The reliability of the spatiotemporal distribution (location) of magnetic sources and the magnitudes of their magnetization depends on the adequacy of taking into account the geometry of objects and the inhomogeneity of the Earth's main magnetic field. In this regard, for the East European Craton for the first time its regional 3D magnetic model for a spherical Earth is developed. To develop the model, we used digital data WDMAM at a height of $5 \mathrm{~km}$, a priori data on the depths of the surface of the crystalline basement and Moho, the temperature distribution, as well as the results of other geological and geophysics researches. According to S.V. Bogdanova, the Eastern European Craton was formed due to the suturation of three segments (Fennoscandia, Volgo-Uralia and Sarmatia) in a time interval of 2,1-1,8 Ga. At the Phanerozoic stage of development, the modern borders of the craton were formed. It is established that a non-uniform distribution of magnetic sources and magnitudes of their magnetization is observed on the boundaries of the craton. The maximum concentration of magnetic sources is characteristic for the edge parts of the craton. The southwestern boundary of the craton is marked by magnetic sources with a magnetization of $(1,0-3,0) A / \mathrm{m}$ at depths of $(10-18 \div 46) \mathrm{km}$. Stretching of the sources is consistent with the stretch of the Trans-European sutural zone and the Baltic-Transnistrian zone of pericratonic troughs (subsidence). The stretching of magnetic sources in the southeast of the craton within Fennoscandia and the Volgo-Uralia is coordinated with the strike of the Phanerozoic

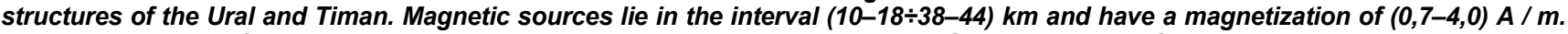
Magnetic sources of the northern (within Fennoscandia) and southern (within Sarmatia) parts of the craton have an end joint with its boundary. The zones of articulation of the EEC segments are also distinguished by sources of regional magnetic anomalies. Magnetic sources of the Central-Russian rift system divide the magnetic crust of the Volgo-Uralia and the weak magnetic crust of Fennoscandia, and the sources of the Volyn-Orsha rift system are Fennoscandia and Sarmatia. Magnetic sources of the Pachelma rift zone are separated by Sarmatia and Volgo-Uralia. We note that approximately the same strike has magnetic anomalies of the Kursk-Bryansk band with maximal values of the magnetization of their sources within the limits of the craton $(>10,0 \mathrm{~A} / \mathrm{m})$. According to the concept of tectonics of lithospheric plates, the magnetic inhomogeneity of the zones of suturation of the segments of the craton and its outer boundaries can be considered as sources of subduction type, which arose at the stage of their formation. In the Riphean and Phanerozoic stages of the development of the lithosphere within the zones of suturation of the segments of the craton and its outer boundaries, magnetic sources of rift nature were formed. Magnetic sources of subduction-reduction and rifting types are characterized by a corresponding metallogenic specialization, therefore the developed model can be used both for tectonic constructions and for small-scale forecasting of minerals.
\end{abstract}

Keywords: East European Craton, 3D magnetic model.

Introduction. The development of three-dimensional magnetic models of the Earth's lithosphere is an integral component to reveal a sources allocation through its section, as well as geological coordination of the results of surface, aerial, stratospheric and satellite magnetic surveys. To obtain the real sources shape and the values of their magnetization from the results of magnetic modeling for large areas, it is necessary to take into account the sphericity of the Earth. In this paper, the task was to develop three-dimentional magnetic model of the territory of the East European Craton (EEC) taking into account the sphericity of the Earth in order to clarify the Earth's crust deep structure.

Data and methods. To date, small-scale magnetic models and magnetization distribution patterns in the lithosphere of EEC have been developed [8, 12, 13, 28 et al.]. For a number of DSS profiles within the Craton as well as its individual parts, magnetic models in the 2- or 3-dimensional variant are constructed in the Cartesian coordinate system [9, 18, 20 et al.].

Within a reasonable compromise between the size of the territory and the detailed studies for the EEC, a scale model of $1: 5000000$ was developed, with the detailing of its south-western part.

To create the initial approximation of the threedimensional magnetic model of the Earth's crust of the East
European Craton, the following data were used: World Digital Magnetic Anomaly Map (WDMAM) at an altitude of $5 \mathrm{~km}$, heat flow distribution data; temperature at the Moho boundary; scheme of distribution of the foundation surface, Moho, as well as other geological and geophysical data [7, $13,19,21,22,24,25]$.

As shown by the experience of previous studies on the construction of the scheme of the deep structure of the EEC $[8,13,14,17$, etc.], in the anomalous magnetic field there is a regional component, the sources of which belong to the lower floor of the Earth's crust. An anomalous magnetic field map [15] was constructed for the analysis of an anomalous magnetic field and the development of a magnetic model of the Earth's crust of the territory of the EEC, using a digital array of WDMAM [25]. Taking into account the scale of the map, one can take an abnormal magnetic field $\Delta B$ for the first approximation of its regional component $\Delta \mathrm{B}_{\mathrm{a}}$, reg, naturally complicated by high-intensity anomalies of local character. An anomaly of the magnetic field was obtained by averaging the original field with a pallet (window) $50 \times 50 \mathrm{~km}$ (for the Kursk magnetic anomaly region $-100 \times 100 \mathrm{~km}$ ). These anomalies are considered as regional and they were used for magnetic modeling. For the territory of Ukraine, a map of the anomalous field $\Delta \mathrm{B}_{\mathrm{a}}$ of $1: 500,000$ scale was used as a basis $[5,10]$. As for the EEC area, the regional 
component was obtained by averaging the data with a window $50 \times 50 \mathrm{~km}$. Thus, 94 regional magnetic anomalies (RMAs) are allocated within the EEC, the sources of which in the model are represented by one and several magnetic blocks.

The magnetoactive layer of the Earth's crust extends to the depths where the Curie temperature of magnetite $580{ }^{\circ} \mathrm{C}$, the main magnetic mineral of the crystalline part of the Earth's crust, is reached. Given the "cold" regime of the lithosphere for a large part of the territory of the EEC [21], the lower limit of this layer may be Moho surface, as a petrological boundary. The upper edge of deep sources in most cases refers to the roof of the diorite layer of the Earth's crust. For the territory of the craton, the depth to this boundary is $(8-15) \mathrm{km}$. Exceptions are the Dnieper-Donetsk avlakogen and the Caspian depression, where the depth of immersion of the crystalline basement reaches $20 \mathrm{~km}$.

The direction of the total magnetization vector as a result of its equilibrium state in the deep parts of the crust corresponds to the direction of the total geomagnetic field strength vector.

Consideration of the spatial inhomogeneity of the main (normal) magnetic field of the Earth BIGRF and the relationship between the components of the induction vector for different parts of the investigated region are important when developing magnetic models of large regions [15]. As shown in [15] for the area of research in the 2005 epoch, the modulus of induction of the main magnetic field varies within the limits of $45000 \div 57400$ nanotesla, and the declination and inclination angle is $\mathrm{DIGRF}_{\mathrm{IGF}}=1^{\circ} \div 19^{\circ}$ and $\mathrm{I}_{\mathrm{IGRF}}=62^{\circ} \div$ $79^{\circ}$ respectively. Naturally, ignoring this can lead to errors both in estimating the magnetization of the sources of the Earth's crust and in their spatial position. The possibility of taking this feature into account is realized in software and algorithmic support of the solution of the direct magnetoprospecting problem for a spherical Earth $[4,6]$.

Results and discussion. The East European craton has an area of 6,7 square $\mathrm{km}$, including the shelves. Within the EEC, the Precambrian crystalline crust is represented in the Baltic and Ukrainian shields, as well as in certain areas of Belarus and the Voronezh crystal massif. The rest of the craton is covered with Late Proterozoic and Phanerozoic sedimentary cover.

The EEC consists of three segments: Fennoscandia, Volgo-Uralia and Sarmatia, which differ in tectonic regime and age of the crust, which have united in the interval of 2,1$1,9 \mathrm{Ga}$. The processes of activation of the craton were reduced to the formation of Riphean rifts in the zones of suturation of segments and its marginal parts [22, 27].

The Fennoscandian segment occupies the northern, northwestern part of the craton. Eastern Fennoscandia, like the Volgo-Uralia, is characterized by the crustal age of 3,8$2,6 \mathrm{Ga}$, the western part of the segment has a paleoproterozoic crust of $1,95-1,65 \mathrm{Ga}$. The thickness of the Earth's crust segment is from $30 \mathrm{~km}$ to $58 \mathrm{~km}$.

Along the northeastern border, the Riphean and Vendian Timan strata were thrusted to Fennoscandia. This is well emphasized by the sources located along the boundary, which differ sharply from their mosaic character in the inner part of the segment (see Fig. 1). Marginal sources with a magnetization of $(0,5 \div 1,5) \mathrm{A} / \mathrm{m}$ are confined to the elevation of M-surface up to $34 \mathrm{~km}$ [24]. It should be noted the southwest fall of the lateral faces of the sources.
Approximately the same ratio of magnetic sources is typical for the northwestern boundary of the segment, hidden under the overturned caledonides of northern Scandinavia. Magnetic sources have magnetization mainly from $1,0 \mathrm{~A} / \mathrm{m}$ to $2,5 \mathrm{~A} / \mathrm{m}$ and are located at depths from 10 $12 \mathrm{~km}$ to $42-44 \mathrm{~km}$.

The south-western boundary of the segment is traced along the line of the Trans-European suture zone. It delineates the ancient EEC and the Epipaleozoic West European platform. According to seismic data, the boundary is reflected by the vertical displacement of the $M$ section by about $10 \mathrm{~km}$, and the thickness of the sedimentary layer increased to $(10-12) \mathrm{km}$ [23]. In the magnetic model, the boundary is represented by a chain of the sources along it with a magnetization of $1-3 \mathrm{~A} / \mathrm{m}$ and the depths from $(10-18) \mathrm{km}$ to $46 \mathrm{~km}$. In accordance with [17], this area is associated with the Baltic-Transnistrian zone of pericratonic subsidences.

Along $30^{\circ}-31^{\circ}$ east longitude magnetic sources form the Pecheneg-Ladoga belt of the submeridional direction, considered as a suture zone of repeated activation [16]. Within the zone, sources with a magnetization of $0,9-$ $2,1 \mathrm{~A} / \mathrm{m}$ are located at depths of $8-10 \mathrm{~km} \div 40-42 \mathrm{~km}$.

The Volgo-Ural segment is represented mainly by the Archean crust, which is completely buried under the Phanerozoic sedimentary cover. However, under it there are numerous Meso-Neoproterozoic avlakogenes and basins, filled with sedimentary rocks with a thickness of (2-10) km. The average thickness of the Earth's crust is about $40 \mathrm{~km}$. In the magnetic model, its central part is characterized by an unordered mosaic nature of sources distribution with location depths from $10-18 \mathrm{~km}$ to $38-44 \mathrm{~km}$ and the magnetization of $0,7-1,5 \mathrm{~A} / \mathrm{m}$. These sources can, presumably, be connected with the system of stable Archean dome-like structures (Fig. 1) [1], whereas linear ones belong to the mobile belts of the Paleoproterozoic [22].

In the east, the Volgo-Ural segment is limited by the hercinides of the Urals, which are thrusted to the craton. In this part of the segment there are intense magnetic sources (up to $4,0 \mathrm{~A} / \mathrm{m}$ ), the strike of which partially corresponds to the strike of its boundary. Further to the southeast, a zone of magnetic bodies also confined to the edge of the segment is clearly distinguished.

The Sarmatian segment is characterized by an average crustal thickness of $48 \mathrm{~km}$ and a strongly magnetized lithosphere [17].

The magnetization of the lower part of the crust, as it has been shown by the results of modeling, is much higher in comparison with the sources of the Volgo-Uralia and Fennoscandia. The spatial orientation of sources within Sarmatia varies in different ways with the extent of both the boundaries of the craton and the large tectonic units of the segment. The south-western, north-western and northeastern boundaries of the segment are characterized by magnetic sources of consonant strike. For the southern edge of the craton, the end joint of magnetic bodies with its boundary is characteristic. High values of magnetization are sources of $\operatorname{Lviv}(3,2 \mathrm{~A} / \mathrm{m})$, Odessa $(3,5 \mathrm{~A} / \mathrm{m})$ and West Ingulets $(3,6 \mathrm{~A} / \mathrm{m})$ RMA. Especially it is worth to note Kursk RMA with the source magnetization up to $10,0 \mathrm{~A} / \mathrm{m}$. 

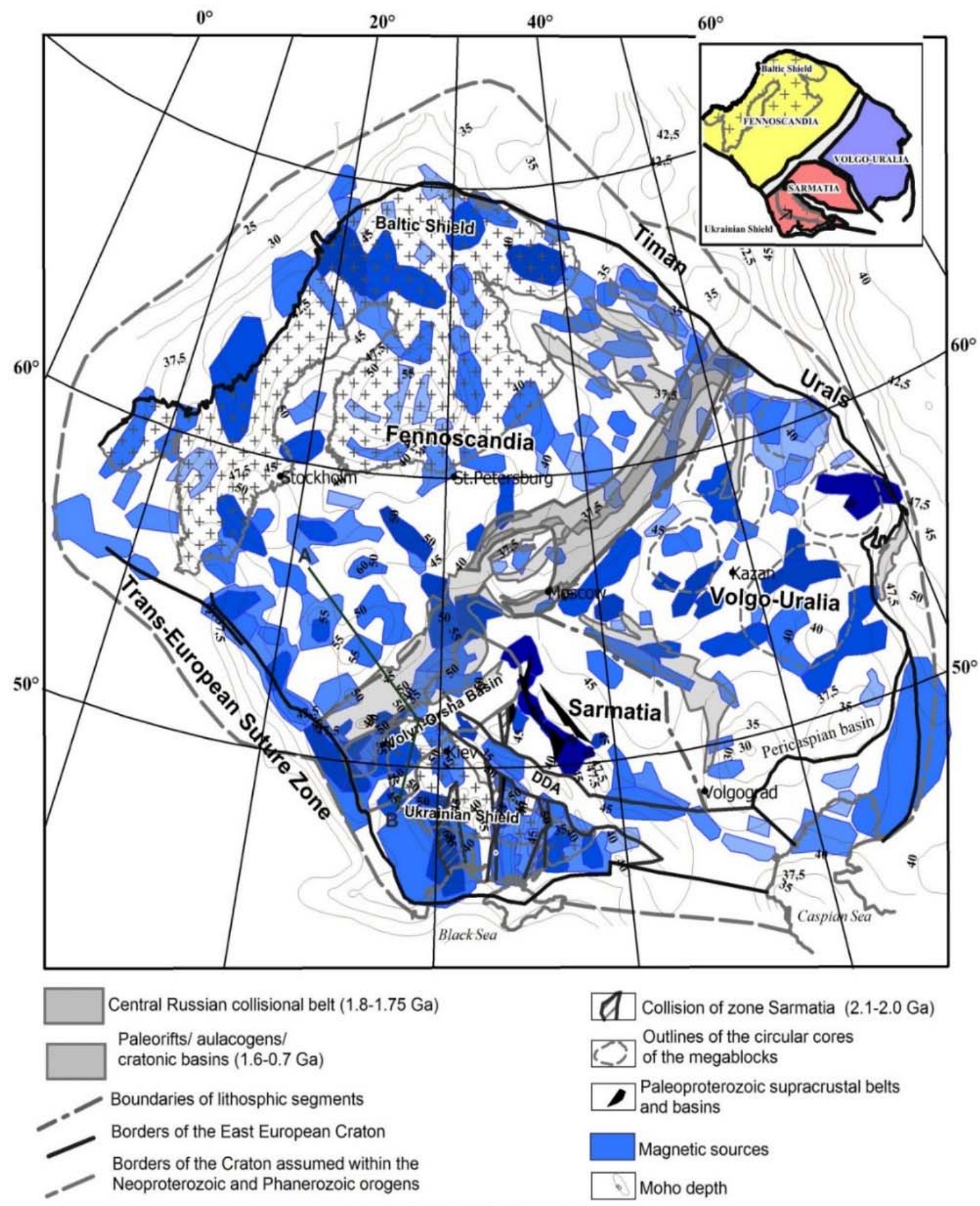

Scale of magnetization, $\mathrm{A} / \mathrm{m}$

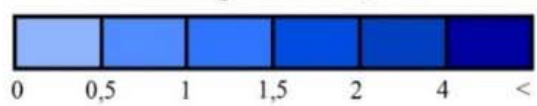

Fig. 1. 3D regional magnetic model of the Earth Crust of the East-European Craton. Tectonic base for S.V. Bogdanova [22]

The magnetic sources junction areas. The East European craton is characterized by rifts and aulacogenes underlying the platform sedimentary depressions. As a rule, meso-Neoproterozoic rifts and aulacogenes are associated with the system of Paleoproterozoic sutures that appeared at the stage of craton formation from individual segments
(Fig. 2). This group includes Pachelma and Central-Russian avlakogens, as well as the Volyn-Orsha Paleorift. A number of Neoproterozoic rifts are confined to passive continental margins. The Phanerozoic Pripyat-Dnieper-Donets rift and the Oslo graben are sharply discordant with respect to the ancient structures of the craton. 


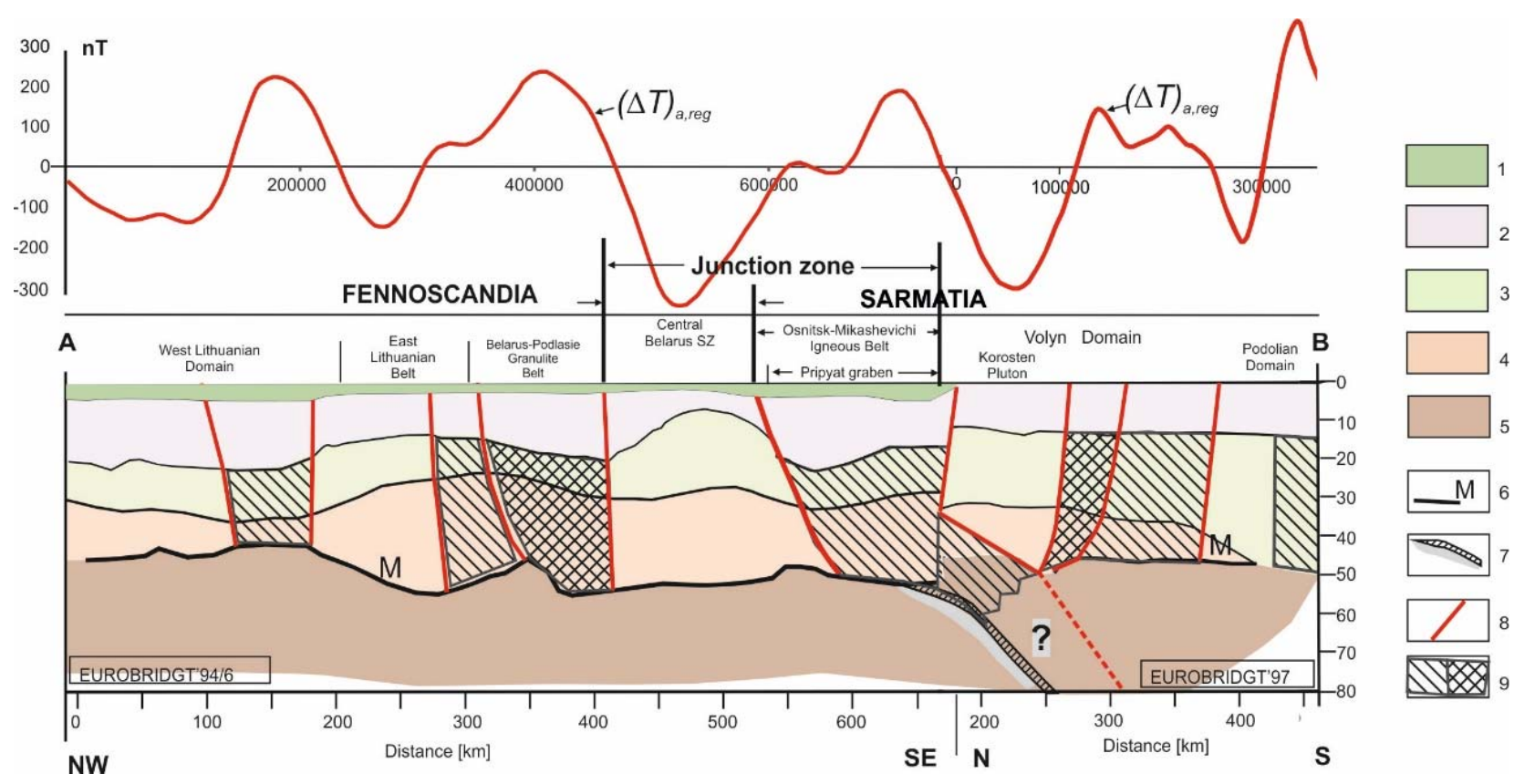

Fig. 2. Magnetic inhomogeneity of the Earth's crust of the junction zone between Fennoscandia and Sarmatia for the EUROBRIDGE transect (Seismic-geological section for [23]):

1 - sedimentary cover; 2 - upper crust; 3 - middle crust; 4 - lower crust; 5 - uppermost mantle; 6 - Moho boundary;

7 - mantle reflector or zone of high-velocity gradient; 8 - Faults; 9 - mean magnetization of the crust $(\mathrm{A} / \mathrm{m})$

Within the East European craton, the three Riphean trascratonic rift systems will inherit zones of the Paleoproterozoic articulations of the Fennoscandian, VolgoUral and Sarmatian segments of the continental crust. Dynamically these systems represent different types of Paleoproterozoic tectonic events. The suture zone of the Pachelma aulacogene was created by thrusting the VolgoUralia onto Sarmatia, the Volyn-Orsha zone of articulation by pushing the Paleoproterozoic crust of Fennoscandia under Sarmatia and the Central Russian suturation zone, probably formed by the collision of the Volgo-Uralia and the Archaean part of Fennoscandia. Rifting within the age is usually accompanied by mafic magmatism.

The Central Russian rift system divides higher magnetic crust of the Volgo-Uralia and weakly magnetic one of Fennoscandia. The magnetization of the sources in this case is up to $1 \mathrm{~A} / \mathrm{m}$ from the side of Fennoscandia and up to $2,0 \mathrm{~A} / \mathrm{m}$ from the Volgo-Ural region. The sources are confined to a system of abrupt faults in the side parts of the aulacogen.

The Volyn-Orsha rift system divides two very different types of crust. The Fennoscandian segment is represented by paleoproterozoic, and Sarmatia is mainly an Archaean. Quantitative interpretation of seismic and magnetic data suggests that the main faults in the crust of Fennoscandia are associated with its immersion under Sarmatia. The OsnitskMikashevich belt is also descending to the southeast along the border of Fennoscandia-Sarmatia, and can be traced to the depths of $100 \mathrm{~km}[3,22]$ forming a subduction zone. The subduction zone and the rift system are clearly distinguished by intensive mosaic sources of the regional class with a magnetization of $0,5-3,0 \mathrm{~A} / \mathrm{m}$ in the magnetic model along the geotransect "EUROBRIDGE" (fig. 2).

The Pachelm rift system is the zone of the suturation of Sarmatia and the Volgo-Uralia [22]. It should be noted that a magnetic source with a magnetization of up to $2,0 \mathrm{~A} / \mathrm{m}$ and bedding depth of $(10-32) \mathrm{km}$ is confined to the southern edge of the aulacogene, which may indicate its dependence on mafic volcanics of Riphean age.

The characteristic features of the Central Russian and Pachelm rift systems are the presence of positive linear magnetic anomalies, clear boundaries of rifts and increased heat flux. On the contrary, the rifts and grabens of the VolynOrsha avlakogen are less developed and have no clearly defined external boundaries with the host environment, and are characterized by a relatively low heat flux [2]

Conclusion. According to $[11,26]$ the tectonotypes of deep sources are subduction-obducted and rift zones of the Earth's crust, as well as zones of transcrustal faults. In accordance with discussed above, the sources of the edge parts of the EEC can be considered as sources of subductionobducted type that originated in the Caledonian-Hercynian stage of the formation of its boundaries. The sources of the joint zones of segments formed in a time interval of 2,1$1,8 \mathrm{Ga}$ are likely to have the same nature $[11,13]$. With the further development and activation of the EEC, riftogenic type sources that originated in the Riphean-Vendian and later stages of the formation of rifts and transcrustal faults are associated. These can be considered the Central Russian and Volyn-Orsha, Pachelma inter-segment rift systems, as well as intra-segment rifts, such as Pripyat-Dnieper-Donets in Sarmatia, Kaltasinsky in the Volgo-Uralia as well as a suture zone of multiple activation within Fennoscandia.

Список використаних джерел

1.Богданова С.В. Земная кора Русской плиты в раннем докембрии / С.В. Богданова. - М. : Наука, 1986. - 220 с.

2. Гарецкий Р.Г. Авлакогены платформ Северной Евразии / Р.Г. Гарецкий // Геотектоника. - 1995. - № 4. - С. 16-28.

3. Гарецкий Р.Г. Тектоногеодинамическая модель сочленения Фенноскандинавского и Сарматского сегментов Восточно-Европейской платформы / Р.Г. Гарецкий, Г.И. Каратаев // Геология и геофизика. - 2011. № 10 (52). - С. 1557-1566.

4. Інтерпретація регіональних магнітних аномалій з врахуванням сфреричності Землі / М.І. Орлюк, В.М. Коваленко-Завойський, І.М. Іващенко, А.В. Марченко. // Моніторинг небезпечних геологічних процесів та екологічного стану середовища : тез. VIII Міжнар. конф. - 2007. - С. 76-77.

5. Карта аномального магнітного поля $(\Delta \mathrm{T})$, України м-бу $1: 1000000 /$ Т.С. Нечаєва, Л.М. Шимків, В.М. Горкавко. $-2002 .-1$ л.

6. Коваленко-Завойський В.М. Математичне забезпечення інтерпретації поля регіональних магнітних аномалій / В.М. Коваленко-Завойський, І.М. Іващенко // Геофіз. журн.. - 2006. - № 5 (28) - С. 18-30.

7. Кутас Р.И. Тепловое поле и геотермический режим литосферы / Р.И. Кутас // Литоссера Центральной и Восточной Европы (обобщение результатов исследований); под ред. А.В. Чекунова. - К., 1993. - С. 114-135.

8. Магнитная модель литосферы Европы / И.К. Пашкевич, В.С. Марковский, М.И. Орлюк и др. - К. : Наук. думка, 1990. - 168 с. 
9. Магнитная модель северо-восточной части Европы / Н.В. Федорова, В.В. Колмогорова, А.Л. Рублев, А.Г. Цидаев // Геофиз, исспедования. -2013 . - № 2 (14). - С. 25-37.

10. Магнитное склонение на территории Украины: результаты наблюдений и вычислений / М.И. Орлюк, А.А. Роменец, А.В. Марченко, И.М. Орлюк, И.Н. Иващенко // Геофиз. журн. - 2015. - № 2 (37). - С. 73-85.

11. Орлюк М.И. Глубинные источники региональных магнитных аномалий: тектонотипы и связь с транскоровыми разломами / М.И. Орлюк, И.К. Пашкевич // Геофиз. журн. - 2012. - № 4(34). - С. 224 -234.

12. Орлюк М.И. Магнитная модель юго-западного края Восточно-Европейской платформы / М.И. Орлюк, И.К. Пашкевич // Геофиз. журн. 1995. - № 6 (17). - С. 31-36.

13. Орлюк М.И. Пространственные и пространственно-временные магнитные модели разноранговых структур литосферы континентального типа / М.И. Орлюк. // Геофиз. журн - 2000 - № 6(22) - С. 148-165.

14. Орлюк М.И. Строение литосферы вдоль геотраверса III. Магнитная модель / М.И. Орлюк // Литосфера Центральной и Восточной Европы. Геотраверсы Ш, VIIIX; под ред. А.В. Чекунова. - К. : Наук. думка, 1993. C. $30-35$.

15. Орлюк M.I. Картографрічне забезпечення розробки 3D магнітної моделі земної кори Східно-Європейської платформи (з урахуванням сферичності Землі) / М.І. Орлюк, А.В. Марченко // Геофізичні технології прогнозування та моніторингу геологічного середовища : матеріали наук. конф. - 2008. - С. 154-155.

16. Пашкевич И.К. Трехмерная геолого-геосизическая модель литосфреры центральной части Карельского кратона / И.К. Пашкевич, Н.В. Шаров, А.С. Савченко, В.И. Старостенко // Геофиз. журн. - 2014. - № 6(36). C. $58-78$.

17. Петромагнитная модель литосферы / И.К. Пашкевич, Д.М. Печерский, А.М. Городницкий и др. - К. : Наук. думка, 1994. - 176 с.

18. Соллогуб В.Б. Литосфера Украины / В.Б. Соллогуб. - К. : Наук. думка, 1986. - 184 с.

19. Схема глубинного строения литоссеры юго-западной части Восточно-Европейской платформы. М-б 1 : 1000000 / А.В. Чекунов, В.Б. Соллогуб, С.С. Красовский и др. $-1992 .-6$ л.

20. Федорова Н.В. Модели намагниченности земной коры по геотраверсу Гранит / Н.В. Федорова. // Уральский геофиз. вест. - 2001. - № 2. - C. 88-93.

21. Artemieva I. Thermal thickness and evolution of Precambrian lithosphere: A global study / I. Artemieva, D. Mooney // Journal of geophysical research. - 2001. - № 108. - P. 16387-16414.

22. Bogdanova S.V. EUROPE|East European Craton / S.V. Bogdanova, R. Gorbachev, R.G. Garetsky // Reference Module in Earth Systems and Environmental Sciences, 2016. - P. 1-18.

23. EUROBRIDGE: new insight into the geodynamic evolution of the East European Craton, in European Lithosphere Dynamics / S.V. Bogdanova, R. Gorbachev, M. Grad et al. // European Lithosphere Dynamics: eds. D.G. Gee, R.A. Stephenson. - London: Geological Society, 2006. - P. 599-625.

24. Grad M. The Moho depth map of the European Plate / M. Grad, T. Tiira, ESC Working Group // Geophysical Journal International. - 2009. № 176. - C. 279-292.

25. Magnetic anomaly map of the world-carte des anomalies magnétiques du monde / J. Korhonen, J.D. Fairhead, M. Hamoudi et al. Paris : Commission for Geological Map of the World 1st Edition.

26. Orlyuk M.I. Tektonic interpretation of 4-dimensional magnetic mode for the south - western part of the East-European platform / M.I. Orlyuk // Eurobridge workshop. - 1996. - P. 28

27. Riphean rifting and major Paleoproterozoic crustal boundaries in the basement of the East European Craton: geology and geophysics I S.V. Bogdanova, I.K. Paskevich, R. Gorbatschev, M.I. Orlyuk // Tectonophysics - 1996 - № 268 - P 1-21.

28. The Magnetic Field of the Earth's Lithosphere / E. Thébault, M. Purucker, K.A. Whaler et al. // Space Science Reviews. - 2010. - P. 95127.doi:10.1007/s11214-010-9667-6.

\section{References}

1. Bogdanova, S. (1986). The Russian platform crust in the Early Precambrian (with reference to the Volgo-Ural segment). Moscow: Nauka, 220 p. [in Russian]

2. Garetsky, R.G. (1995). Aulacogens of the cratons in Northern Euroasia. Geotektonika, 4, 16-28. [in Russian].

3. Garetsky, R.G., Karataev, G.I. (2011). Tectonogeodynamic model junction of Fennoscandian and Sarmatian segments of the East European Platform. Geology and Geophysics, 52(10), 1557-1566. [in Russian].

4. Orlyuk, M.I., Kovalenko-Zavoisky, V.M., Ivashchenko, I.M., Marchenko, A.V. (2007). Interpretation of regional magnetic anomalies for spherical Earth. Thesis of VIIIth International conference "Monitoring of a dangerous geological processes and environmental ecological state", 76-77. [In Ukrainian]
5. Nechaeva, T.S., Shymkiv, L.M., Gorkavko, V.M. (2002). Map of anomaly magnetic field $(\Delta T)_{a}$ Ukraine. Scale of 1:1000 000.Kyiv, 1sh. [In Ukrainian].

6. Kovalenko-Zavoisky, V.M., Ivashchenko, I.M. (2006). Mathematical support of $\Delta \mathrm{Ba}$ field interpretation. Geophysical Journal, 28(5), 18-30. [In Ukrainian].

7. Kutas, R.I. (1993). Thermal field and geothermal regime of the lithosphere. In: Chekunov, A.V. (Eds.) Lithosphere Central and Eastern Europe. Summary of the Studies. Kiev: Naukova dumka, 115-132. [in Russian]

8. Pashkevich, I.K., Markovskiy, V.S., Orlyuk, M.I., Eliseeva, S.V. Mozgovaya, A.P., Tarashchan, S.A. (1990). Magnetic model of the lithosphere Europe. Kiev: Naukova Dumka, 168 p. [in Russian].

9. Fedorova, N.V., Kolmogorova, V.V., Rublev, A.L., Tsidaev, A.G. (2013). The magnetic model of the north-eastern region of Europe. Geofizicheskiye issledovaniya, 14(2), 25-37. [In Russian].

10. Orlyuk, M.I., Romenets, A.A., Marchenko, A.V., Orlyuk, I.M., Ivashchenko, I.N. (2015). Magnetic declination in the territory of Ukraine: the results of observations and calculations. Geophysical Journal, 37 (2). 73-85. [In Russian].

11. Orlyuk, M.I., Pashkevich, I.K. (2012). Deep sources of regional magnetic anomalies: tectonotypes and relation with transcrustal faults. Geophysical Journal, 34(4), 224-234. [In Russian].

12. Orlyuk, M.I., Pashkevich, I.K. (1995). Magnetic model of the Earth's crust for the South-East of the East-European Platform. Geophysical Journal, 17(6), 31-36. [In Russian]

13. Orlyuk, M.I. (2000). Spatial and spatio-temporal magnetic models of different rank structures lithosphere of the continental type. Geophysical Journal, 22(6), 148-165. [In Russian].

14. Orlyuk, M.I. (1993). Geotraverse III. Magnetic model. In: Chekunov, A.V. (Eds.) Lithosphere of Central and Eastern Europe. Geotraverses III, VII, IX. Kiev: Naukova Dumka, 30-35. [In Russian]

15. Orlyuk, M.I., Marchenko, A.V. (2008). Mapping support for the 3D magnetic model the earth crust of the East European platform (for spherical Earth). Thesis of International Scientific Conference "Geophysical technologies for predicting and monitoring of geological media". Lviv, 6-10 October 2008, 154-155. [In Ukrainian]

16. Pashkevich, I.K., Sharov, N.V., Savchenko, A.S., Starostenko, V.I. (2014) Three-dimensional geological-geophysical lithosphere model of the central part of the Karelian craton. Geophysical Journal, 36(6), 58-78. [in Russian]

17. Pashkevich, I.K., Orlyuk, M.I., Eliseeva, S.V. (1994). Platformal areas of Europe. In: Pechersky, D.M. (Eds.) Petromagnetic Model of the Lithosphere. Kiev: Naukova Dumka, 109-124. [In Russian].

18. Sollogub, V.B. (1986). Lithosphere of Ukraine. Kiev: Naukova Dumka, 184 p. [In Russian].

19. Chekunov,A.V. (Ed.) (1992). Scheme of lithospheric deep structure of southwestern part of the East European Platform. Sc. 1000000. Kyiv: Goscomgeology, 6sh. [In Russian]

20. Fedorova, N.V. (2001). Crustal magnetization models along the Granite geotraverse. Uralsky geofizichesky vestnik, 2, 88-93. [In Russian].

21. Artemieva, I., Mooney, D. (2001). Thermal thickness and evolution of Precambrian lithosphere: A global study. Journal of geophysical research, 106, B8, 16387 -16414. doi:10.1029/2000JB900439

22. Bogdanova, S., Gorbatschev, R., Garetsky ${ }_{2}$ R.G. (2016). EUROPE|East European Craton in book Reference Module in Earth Systems and Environmental Sciences, 1-18. doi:10.1016/B978-0-12-4095489.10020-X

23. Bogdanova, S., Gorbachev, R., Grad, M. et al. (2006). EUROBRIDGE: new insight into the geodynamic evolution of the East European Craton. In: Gee, D.G., Stephenson, R.A. (Eds.). European Lithosphere Dynamics. London: Geological Society, 32, 599-625.

24. Grad, M., Tiira, T., ESC Working Group. (2009). The Moho depth map of the European Plate. Geophysical Journal International, 176, 279-292. http://dx.doi.org/10.1111/j.1365-246X.2008.03919.x

25. Korhonen, J., Fairhead, J.D., Hamoudi, M., Hemant, K., Lesur, V., Mandea, M. Maus, S., Purucker, M., Ravat, D. Sazonova, T. Thébault E. (2007). Magnetic anomaly map of the world-carte des anomalies magnétiques du monde. Commission for Geological Map of the World 1st Edition. Paris, France.

26. Orlyuk, M.I (1996). Tektonic interpretation of 4-dimensional magnetic model for the south - western part of the East-European platform. EUROBRIDGE workshop. 8-15 June 1996. Oskarshamn, Sweden, 28.

27. Bogdanova, S.V., Pashkevich, I.K., Gorbatschev, R., Orlyuk, M.I. (1996). Riphean rifting and major Paleoproterozoic crustal boundaries in the basement of the East European Craton: geology and geophysics. Tectonophysics, 268, 1-21.

28. Thébault, E., Purucker, M., Whaler, K.A., Langlais, B., Sabaka, T.J. (2010). The Magnetic Field of the Earth's Lithosphere. Space Science Reviews, 95-127. doi:10.1007/s11214-010-9667-6

Надійшла до редколегії 19.10.17 
М. Орлюк, д-р геол. наук, зав. відділу геомагнетизму

E-mail: orlyuk@igph.kiev.ua

А. Марченко, мол. наук. співроб.

E-mail: andrey_marchenko@ukr.net,

М. Бакаржієва, старш. наук. співроб.

E-mail: bakarjieva@ukr.net

Інститут геофізики ім. С.І. Субботіна НАН України

пр. Акад. Палладіна, 32, м. Київ, 03680, Україна

\section{D МАГНІТНА МОДЕЛЬ ЗЕМНОЇ КОРИ СХІДНОЄВРОПЕЙСЬКОГО КРАТОНУ 3 УРАХУВАННЯМ СФЕРИЧНОСТІ ЗЕМЛІ ТА ІІІ ТЕКТОНІЧНА ІНТЕРПРЕТАЦІЯ}

Геомагнітне поле широко застосовується для отримання інформації щодо глибинної будови та розвитку літосфери Землі, дрібномасштабного прогнозування корисних копалин, а також вирішення низки екологічних завдань. Найбільш вагомі результати отримуються за рахунок розробки 2D, 3D та 4D магнітних моделей земної кори (літосфери) в яких відображаються просторовий та просторово-часовий розподіл магнітних джерел. Достовірність просторово-часового розподілу (розташування) магнітних джерел і величин їхньої намагніченості залежить від адекватності врахування геометрії об'єктів і неоднорідності головного магнітного поля Землі ВІGRF. У зв'язку з цим для Східноєвропейського кратону вперше розроблено його регіональну 3D магнітну модель для сферичної Землі. Для розробки моделі використано цифрові дані WDMAM на висоті 5 км, апріорні дані щодо глибин залягання поверхні кристалічного фундаменту та Мохо, розподілу температур, а також результати інших геолого-геофізичних досліджень. Згідно із С.В. Богдановою, СхідноЄвропейський кратон сформувався за рахунок зчленування трьох сегментів (Феноскандії, Волго-Уралії та Сарматії) у часовому інтервалі 2,1-1,8 млрд років. На фанерозойському етапі розвитку були сформовані його сучасні границі. Установлено, що в межах кратону спостерігається нерівномірний розподіл магнітних джерел і величин їхньої намагніченості. Максимальна концентрація магнітних джерел характерна для його крайових частин. Південно-західна границя кратону відмічається магнітними джерелами 3 намагніченістю 1,0-

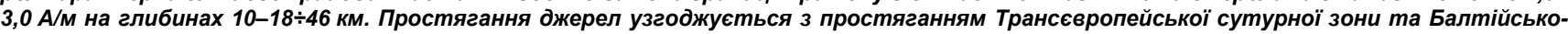
Придністровської зони перикратонних прогинів (опускань). Простягання магнітних джерел на північному сході кратону в межаж Феноскандії та Волго-Уралії узгоджене з простяганням фанерозойських структур Уралу та Тіману. Магнітні джерела залягають в інтервалі

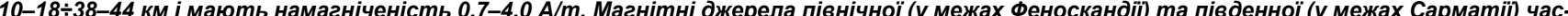
тин кратону мають торцеве зчленування з його границею. Зони зчленування сегментів СєК також виділяються джерелами регіональних магнітних аномалій. Магнітні джерела Центрально-Російської рифтової системи розділяють магнітну кору Волго-Уралії та слабкомагнітну кору Феноскандії, а джерела Волинсько-Оршанської рифтової системи - Феноскандії і Сарматії. Магнітні джерела Пачелмської рифтової зони розділяють Сарматію та Волго-Уралію. Зауважимо, що приблизно таке ж простягання мають магнітні аномалії КурськоБрянської смуги з максимальними, у межах кратону, величинами намаеніченості їхніх джерел (>10,0 A/м). Зәідно із концепцією тектоніки літосферних плит магнітні неоднорідності зон зчленування сегментів кратону та його зовнішніх границь можуть розглядатися як джерела субдукційно-обдукційного типу, що виникли на етапі їхнього формування. На рифейському та фанерозойському етапах розвитку літосфери в межах зон зчленування сегментів кратону та його зовнішніх границь формувалися магнітні джерела рифтової природи. Магнітні джерела субдукційно-обдукційного та рифтогенного типів характеризуються відповідною металогенічною спеціалізацію, тому розроблена модель може бути використана як для тектонічних $і$ геодинамічних побудов, так і для дрібномаситабного прогнозування корисних копалин.

Ключові слова: Східноєвропейський кратон, 3D магнітна модель.

М. Орлюк, д-р геол. наук, зав. отделом геомагнетизма

E-mail: orlyuk@igph.kiev.ua,

А. Марченко, мл. науч. сотр.

E-mail: andrey marchenko@ukr.net,

М. Бакаржиева, ст. науч. Стр

E-mail: bakarjieva@ukr.net

Институт геофизики им. С.И. Субботина НАН Украины

пр. Акад. Палладина, 32, г. Киев, 03680, Украина

\section{D МАГНИТНАЯ МОДЕЛЬ ЗЕМНОЙ КОРЫ ВОСТОЧНОЕВРОПЕЙСКОГО КРАТОНА С УЧЕТОМ СФЕРИЧНОСТИ ЗЕМЛИ И ЕЕ ТЕКТОНИЧЕСКАЯ ИНТЕРПРЕТАЦИЯ}

Геомагнитное поле широко применяется для получения информации о глубинном строении и развитии литосферы Земли, мелкомасштабного прогнозирования полезных ископаемых, а также решения ряда экологических задач. Наиболее весомые результаты получаются за счет разработки 2D, 3D и 4D магнитных моделей земной коры (литосферы) в которых отражаются пространственное и пространственно-временное распределение магнитных источников. Достоверность пространственно-временного распределения (расположение) магнитных источников и величин их намагниченности зависит от адекватности учета геометрии объектов и неоднородности главного магнитного поля Земли ВIGRF. В связи с этим для Восточноевропейского кратона впервые разработана его региональная 3D магнитная модель для сферической Земли. Для разработки модели использованы цифровые данные WDMAM на высоте 5 км, априорные данные о глубине залегания поверхности кристаллического фундамента и Мохо, распределения температур, а также результаты других геолого-геофизических исследований. Согласно С.В. Богдановой, Восточноевропейский кратон сформировался за счет сочленения трех сегментов (Фенноскандии, Волго-Уралии и Сарматии) во временном интервале 2,1-1,8 млрд лет. На фанерозойском этапе развития были сформированы современные его границы. Установлено, что в пределах кратона наблюдается неравномерное распределение магнитных источников и величин их намагниченности. Максимальная концентрация магнитных источников характерна для его краевых частей. Юго-западная граница кратона отмечается магнитными источниками с намагниченностью 1,0-3,0 А/м

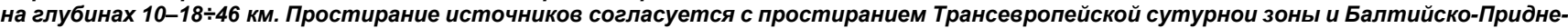
стровской зоны перикратонных прогибов (опусканий). Простирание магнитных источников на северо-востоке кратона - в пределах Феноскандии и Волго-Уралии согласно с простиранием фанерозойских структур Урала и Тимана. Магнитные источники залегают в интервале 10-18 $\div$ 38-44 км и имеют намагниченность 0,7-4,0 A/m. Магнитные источники северной (в пределах Фенноскандии) и южной (в пределах Сарматии) частей кратона имеют ториевое сочленение с его границей. Зоны сочленения сегментов ВЕК также выделяются источниками региональных магнитных аномалий. Магнитные источники Центрально-Российской рифтовой системы разделяют магнитную кору Волго-Уралии и слабомагнитную кору Фенноскандии, а источники Волынско-Оршанской рифтовой системы Фенноскандии и Сарматии. Магнитные источники Пачелмской риффтовой зоны разделяют Сарматию и Волго-Уралию. Заметим, что примерно такое же простирание имеют магнитные аномалии Курско-Брянской полосы с максимальными, в пределах кратона, величинами намагничености их источников (>10,0 A/м). Согласно концепции тектоники литосферных плит магнитные неоднородности зон сочленения сегментов кратона и его внешних границ могут рассматриваться как источники субдукционно-обдукционного типа, возникшие на этапе их формирования. На рифейском и фанерозойском этапах развития литосферы, в пределах зон сочленения сегментов кратона и его внешних границ, формировались магнитные источники рифтовой природы. Магнитные источники субдукционно-обдукционного и рифтогенного типов характеризуются соответствующей металлогенической специализацией, поэтому разработанная модель может быть использована как для тектонических и геодинамических построений, так и для мелкомаситабного прогнозирования полезных ископаемых.

Ключевые слова: Восточноевропейский кратон, 3D магнитная модель. 